\title{
Airborne observation of mixing across the entrainment zone during PARADE 2011
}

\author{
Florian Berkes $^{1,2, a}$, Peter Hoor ${ }^{1}$, Heiko Bozem ${ }^{1}$, Daniel Kunkel ${ }^{1}$, Michael Sprenger ${ }^{3}$, and Stephan Henne ${ }^{4}$ \\ ${ }^{1}$ Institute for Atmospheric Physics, Johannes Gutenberg University Mainz, Mainz, Germany \\ ${ }^{2}$ Department of Atmospheric Chemistry, Max Planck Institute for Chemistry, Mainz, Germany \\ ${ }^{3}$ Institute for Atmospheric and Climate Science, ETH Zurich, Zürich, Switzerland \\ ${ }^{4}$ Empa Swiss Federal Laboratories for Materials Science and Technology, Dübendorf, Switzerland \\ anow at: Institute of Energy and Climate Research-8: Troposphere, Forschungszentrum Jülich GmbH, Jülich, Germany
}

Correspondence to: Florian Berkes (f.berkes@ fz-juelich.de)

Received: 23 September 2015 - Published in Atmos. Chem. Phys. Discuss.: 27 October 2015

Revised: 13 April 2016 - Accepted: 1 May 2016 - Published: 18 May 2016

\begin{abstract}
This study presents the analysis of the structure and air mass characteristics of the lower atmosphere during the field campaign PARADE (PArticles and RAdicals: Diel observations of the impact of urban and biogenic Emissions) on Mount Kleiner Feldberg in southwestern Germany during late summer 2011. We analysed measurements of meteorological variables (temperature, moisture, pressure, wind speed and direction) from radio soundings and of chemical tracers (carbon dioxide, ozone) from aircraft measurements. We focus on the thermodynamic and dynamic properties that control the chemical distribution of atmospheric constituents in the boundary layer. We show that the evolution of tracer profiles of $\mathrm{CO}_{2}$ and $\mathrm{O}_{3}$ indicate mixing across the inversion layer (or entrainment zone). This finding is supported by the analysis of tracer-tracer correlations which are indicative for mixing and the relation of tracer profiles in relation to the evolution of the boundary layer height deduced from radio soundings. The study shows the relevance of entrainment processes for the lower troposphere in general and specifically that the tracer-tracer correlation method can be used to identify mixing and irreversible exchange processes across the inversion layer.
\end{abstract}

\section{Introduction}

The evolution of the planetary boundary layer (PBL) from stably stratified in the morning to well mixed in the afternoon is a multifaceted process and potentially leads to enhanced mixing between the PBL and the free troposphere (FT) (Stull, 1988). At sunset, a stable boundary layer with low turbulence intensity grows near the surface (Mahrt, 2014). Between this layer and the FT, a neutrally stratified layer remains, resulting from the decay of turbulence of the convective PBL during daytime. This layer, called the residual layer, maintains the chemical composition of the original convective PBL (Stull, 1988). The turbulent-convective PBL and the overlaying FT are separated by the capping inversion, which often acts as a transport barrier. This barrier, which is indicated by changes of the vertical gradients of temperature, humidity, aerosol content and chemical constituents, can be overcome by frontal activity (Sinclair et al., 2010). Frontal systems ahead of the respective cold and warm sectors of a cyclonic depression lead to vertical exchange between the PBL and the FT and potentially mix both air masses (Donnell et al., 2001). This is also the case for shallow and deep convection (e.g. Flaty et al., 1995; Hauf et al., 1995). The so-called entrainment zone (EZ) is a layer of intermittent turbulence at the top of the PBL where air masses from the FT are entrained into the capping inversion and thus can interact with convective thermals from the PBL (e.g. Angevine, 2007; Bange et al., 2007). Based on lidar (Träumner et al., 2011), wind profiler (Cohn and Angevine, 2000) and ceilometer measurements (Eresmaa et al., 2006), the extent of the EZ was estimated to be $20-40 \%$ of the PBL depth (Martin et al., 2014).

Airborne flux measurements of heat and moisture were used to determine the impact of entrainment on their budgets 
(e.g. Driedonks and Tennekes, 1984; Canut et al., 2010), and to understand the influence of entrainment on the development of boundary layer clouds (Stevens et al., 2003) and the decay of stratocumulus clouds (e.g. Lilly, 1968). Malinowski et al. (2013) showed that turbulent mixing between the cloud top and the FT depends on the thermodynamic properties (static stability) and wind shear (dynamic instability). Moreover, radiative effects can change the entrainment flux at the cloud tops and lead to exchange and mixing as well between the FT and PBL (Moeng et al., 1999).

Modelling studies revealed that changes of the (static) stability, low-level wind shear, and turbulent motions affect not only the growth of the boundary layer but also the entrainment at the PBL top (e.g. Driedonks and Tennekes, 1984; Sullivan et al., 1998; Cohen, 2000). Lock et al. (2000) showed that mixing and entrainment at the top of the PBL depend on the surface buoyancy flux, the inversion strength and on the influence of wind shear (Conzemius and Fedorovich, 2006).

In recent years substantial efforts have been made to understand the driving physical processes of temperature and humidity transport during the growth or decay of the PBL as summarised by Lothon et al. (2014). It is still difficult to quantify the role of the EZ for the mixing of trace gases, because of its high spatial, vertical and temporal variability (Martin et al., 2014). Vila-Guerau de Arellano (2004) was able to show that the downward transport of $\mathrm{CO}_{2}$ from the FT into the PBL can enhance or reduce $\mathrm{CO}_{2}$ mixing ratios within the PBL which then can lead to a misinterpretation of possible $\mathrm{CO}_{2}$ sources. Vertical gradients of ozone exist as well between the PBL and FT, and they are strongly affected by transport processes and chemical reactions. Measurements and modelling studies of $\mathrm{O}_{3}$ revealed that convective transport of ozone precursors leads to chemical ozone formation in the FT and enhances the background concentrations (Hov and Flatoy, 1997; Henne et al., 2005). Cooper et al. (2015) highlighted that surface air quality regulations in the US strongly depend on accurate knowledge of baseline ozone, which is defined as ozone transported downwind from anthropogenic and natural sources, while forecast of baseline ozone needs large knowledge of all different transport processes. This includes intercontinental transport from Asia, which is often associated with episodes of enhanced ozone concentrations over large parts of the western US that is located at relatively high altitudes (Lin et al., 2012). Moreover, downward transport of ozone-rich air from the FT can enhance ozone mixing ratio in the PBL (Beck et al., 1997; McKendry and Lundgren, 2000; Jaffe, 2011).

Neuman et al. (2012) used tracer-tracer $\left(\mathrm{CO}-\mathrm{O}_{3}\right)$ correlations to identify the in-mixing of ozone from the FT into the PBL. This approach is commonly used to identify stratosphere-troposphere exchange (e.g. Fischer et al., 2000; Hoor, 2002). Generally the approach makes the assumption of two well-mixed reservoirs, which give rise to linear tracer-tracer relationships in the case of mixing. How- ever, the boundary layer acts as a barrier for mixing and often exhibits strong trace gas gradients. Therefore the distribution of data points in tracer-tracer scatter plots sub-divide into distinct groups depending on the mixing ratios of the respective well-mixed reservoirs. Mixing between these air masses leads to linear connections between these groups (mixing lines).

Handisides (2001) presented ozone and peroxy radical observations from the local valley and from Mount Kleiner Feldberg and linked his findings to transport within different boundary layer structures in summertime. Moreover during winter, Wetter (1998) observed on the top of Mount Kleiner Feldberg CO plumes transported out of the stable boundary layer below the summit. In both studies the PBL structure was not investigated in detail. However, this is necessary to understand and interpret the temporal evolution of the spatial distribution of atmospheric trace species measured within and above the PBL, especially over complex terrain where handover processes between the PBL and the FT are additionally triggered by thermally induced flow systems (Kossmann et al., 1999; Henne et al., 2004).

In this study, we will use $\mathrm{CO}_{2}$ and $\mathrm{O}_{3}$ to study mixing across the EZ with the tracer-tracer correlation method. Both trace species have been measured by aircraft during the field campaign PARADE at Mount Kleiner Feldberg in late summer 2011, and are used for the first time together to identify mixing and transport within this atmospheric region. Additionally we discuss possible processes which lead to mixing across the entrainment zone. In this context we focus on the boundary layer development and the weather conditions. We will first present the synoptic condition during the day of measurements and put it into perspective with the entire situation of the measurement campaign. We focus on the diurnal evolution of the boundary layer which we determined with balloon and ceilometer measurements. We then present the results of the aircraft trace species measurements. Finally, we discuss possible processes which may be responsible for the measured distribution of $\mathrm{CO}_{2}$ and $\mathrm{O}_{3}$ and its influence from local mixing and long-range transport.

\section{Measurement and methods}

\subsection{PARADE 2011}

The PARADE (PArticles and RAdicals: Diel observations of the impact of urban and biogenic Emissions) field campaign took place in August and September 2011 located at the Taunus Observatory at the summit of Mount Kleiner Feldberg ( $825 \mathrm{ma.s.1}$.), about $20 \mathrm{~km}$ northwest of Frankfurt am Main in southwestern Germany. The goal of PARADE was to study the impact of summertime biogenic and urban emissions in a semi-remote environment. A comprehensive set of measurements of several reactive species and meteorological variables were conducted during PARADE, also including 
in situ measurements of ozone and carbon dioxide (Phillips et al., 2012; Bonn et al., 2014; Li et al., 2015).

Mount Kleiner Feldberg is mostly covered with coniferous forest, except on the top where the observations took place during PARADE. Meteorological measurements for temperature, wind, humidity, global radiation are performed by a permanently operating observatory of the German Weather Service (DWD) and of the State of Hessen environmental agency (HLUG) (Crowley et al., 2010). The station is known for its quite remote character under prevailing northwesterly winds (Klein et al., 2010). However, this rural region is affected by pollution from the Rhine-Main Area (including the cities of Frankfurt/Main, Wiesbaden, and Mainz) when wind directions have a southerly component. The area north of Mount Kleiner Feldberg $(50-100 \mathrm{~km})$ is less populated and without major industry. In the direct vicinity of Mount Kleiner Feldberg are a few main roads, some small towns within $5 \mathrm{~km}$, and two similarly sized mountain peaks: Großer Feldberg (878 m) and Altkönig (798 m).

During this field campaign the synoptic conditions involved predominately south westerly winds, mainly related to troughs over the northeastern Atlantic and to high pressure systems over central Europe. The south-westerly winds advected enhanced levels of anthropogenic pollution to Kleiner Feldberg and were interrupted by northern to north easterly winds several times. In these cases the probed air masses showed rather low levels of anthropogenic pollution (Phillips et al., 2012). We will present additional details on the synoptic conditions below.

\subsection{Measurements}

\subsubsection{Aircraft instrumentation}

A P68D Partenavia turbo prop aircraft operated by Enviscope $\mathrm{GmbH}$ (www.enviscope.de, last access: 12 November 2014) was equipped with several instruments to perform measurements in and above the planetary boundary layer on 3 days (31 August, 2 and 6 September 2011) during the campaign. The aircraft flew five research flights from Mainz to Mount Kleiner Feldberg. Ascending profiles were flown up and downstream of the surface station, while descending profiles were performed directly over Mount Kleiner Feldberg. The ascending flight legs were conducted in different regions and are not included in the averaged profiles of the following analysis. The descending flight legs were flown in spirals with a diameter of about $10-15 \mathrm{~km}$. The maximum flight altitude was $3000 \mathrm{~m}$ a.s.l and the flight time was approximately 2 to 3 hours. A typical flight track is shown in Fig. 1 and illustrates the sampling strategy. In total, 13 descent profiles were obtained at different locations and times for each variable.

$\mathrm{CO}_{2}$ was measured with a modified commercial $\mathrm{CO}_{2} / \mathrm{H}_{2} \mathrm{O}$ analyser (LI-6262, LI-COR Inc.) with a total uncertainty of $0.55 \mathrm{ppmv}$ (= one standard deviation $\sigma$ ) determined from regular in-flight calibrations and a time

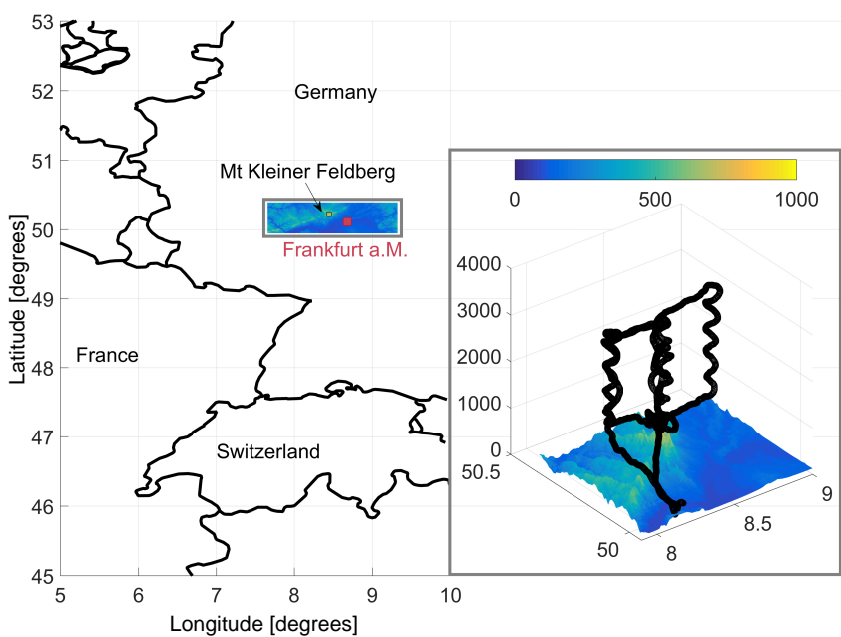

Figure 1. Topographic map (colour bar in $\mathrm{m}$ ) of the Rhein-Main Area in southwest Germany near Frankfurt am Main including the flight pattern on 6 September 2011 (black line). Vertical profiles are indicated by the flight track spirals. All descending profiles were flown near the summit of Mount Kleiner Feldberg, while ascending profiles have been taken up- and downwind.

resolution of $1 \mathrm{~Hz}$ (Gurk et al., 2008). Ozone $\left(\mathrm{O}_{3}\right)$ was measured by UV absorption every $10 \mathrm{~s}$ with the commercial gas analyser O342M (Environnement S.A.) with a total uncertainty of $1.3 \mathrm{ppbv}$ for a moist air mass with less than $10 \mathrm{~g} \mathrm{~kg}^{-1}$ specific humidity (Köllner, 2013). The response time of the instruments $(5 \% / 95 \%)$ was $3 \mathrm{~s}\left(\mathrm{CO}_{2}\right)$ and $9 \mathrm{~s}$ $\left(\mathrm{O}_{3}\right)$, and the final data correction accounted for different residence times in the inlet lines. The ambient temperature and moisture were measured every second with a commercial HMP230 (Vaisala) with an accuracy of two to three percent for relative humidity and $0.5^{\circ} \mathrm{C}$ for temperature. The ambient pressure (SETRA Model 270) was measured with an accuracy of $0.55 \mathrm{hPa}$ (Enviscope $\mathrm{GmbH}$, personal communication, 2014). The particle number concentration was measured by the Optical Particle Counter (Grimm SKYOPC 1.129) for a size range of $0.25-32 \mu \mathrm{m}$ (32 channels) and a time resolution of $1 \mathrm{~Hz}$. Additionally, particle number concentrations of particles with diameters between $10 \mathrm{~nm}$ and $5 \mu \mathrm{m}$ were measured with a modified condensation particle counter (CPC-Modell 3007, TSI) every second. These measurements are reported for standard temperature $(273.15 \mathrm{~K})$ and pressure $(1013.25 \mathrm{hPa})$ conditions (STP).

Three-second average measurements are analysed corresponding to a spatial resolution of about $150 \mathrm{~m}$ at an average aircraft velocity of $50 \mathrm{~m} \mathrm{~s}^{-1}$. The aircraft descent took about $10 \mathrm{~min}$, so that the $3 \mathrm{~s}$ data yielded a vertical resolution of 3 $4 \mathrm{~m}$. For further analysis of the vertical structure of the trace gases measurements between 1000 and 3000 ma.s.l. Kleiner Feldberg (approx. $150 \mathrm{~m}$ over the mountain summit), each vertical profile is linearly interpolated to a uniform vertical grid with $10 \mathrm{~m}$ resolution. 


\subsubsection{Surface-based and radiosonde measurements}

Vertical profiles of temperature, relative humidity and position were obtained from 174 radiosondes (GRAW DFM06, www.graw.de, last access: 12 November 2014). Between four and ten radiosondes were launched each day, starting usually $1 \mathrm{hr}$ before sunrise and ending 1 hour after sunset. The sampling rate of $1 \mathrm{~Hz}$ results in a vertical resolution of about 1-2 $\mathrm{m}$. The data have been interpolated onto an equidistant vertical grid with $20 \mathrm{~m}$ resolution. The pressure is obtained from these observations. Wind speed and wind direction are calculated from temporal changes of the current position of the balloon relative to the surface station. The near-surface temperature measurements were compared to the temperature measurement from the local observatory. The comparison revealed a high positive correlation with an $r^{2}=0.99$ and a mean absolute deviation of $\left|T_{\mathrm{RS}}-T_{\mathrm{DWD}}\right|=0.56 \pm 0.50^{\circ} \mathrm{C}$.

The Ceilometer CHM $15 \mathrm{k}-\mathrm{x}$ from Jenoptik (www. jenoptik.com, last access: 12 November 2014) is primarily designed to determine the cloud base from $200 \mathrm{~m}$ to $15 \mathrm{~km}$ above ground. In the absence of clouds, the backscatter signal can also be used for detecting aerosol layers (Münkel et al., 2007). The laser emits a light pulse with a repetition rate of $5-7 \mathrm{kHz}$, a pulse time of $1 \mathrm{~ns}$ and a wavelength of $\lambda=1064 \mathrm{~nm}$, with a vertical resolution of $15 \mathrm{~m}$. Thus, every $30 \mathrm{~s}$ a vertical backscatter profile is obtained.

Surface-based $\mathrm{CO}_{2}$ measurements were performed with a commercial $\mathrm{CO}_{2} / \mathrm{H}_{2} \mathrm{O}$ analyser (LI-6262, LI-COR Inc.) with a total uncertainty of 2 ppmv determined from regular calibrations and a time resolution of $1 \mathrm{~Hz}$. Additionally $\mathrm{CO}_{2}$ was measured from the mobile laboratory (MoLa) (Drewnick et al., 2012) with a commercial $\mathrm{CO}_{2} / \mathrm{H}_{2} \mathrm{O}$ analyser (LI-840, LI-COR Inc.) without regular calibrations and a separate inlet line. These data were provided as 10 min mean values and are only used here to illustrate the diurnal cycle of $\mathrm{CO}_{2}$. Surface-based ozone measurements were performed by various instruments with different techniques at different locations during this campaign. At Mount Kleiner Feldberg $\mathrm{O}_{3}$ was measured by UV absorption with a commercial $\mathrm{O}_{3}$ analyser (Model 49, Thermo Environmental Instruments Inc.). The total uncertainty was $5 \%(2 \sigma)$ and the data were provided as $10 \mathrm{~min}$ averages (Li et al., 2015). HLUG provides 30 min averaged $\mathrm{O}_{3}$ measurements using a commercial UV absorption instrument (API 400) (Crowley et al., 2010).

\subsection{Determination of the planetary boundary layer height}

The planetary boundary layer height (PBLH) was calculated from the radio soundings using the surface based bulk Richardson number $R i_{\mathrm{B}}$ (Vogelezang and Holtslag, 1996; Seibert et al., 2000). The dimensionless bulk Richardson number $R i_{\mathrm{B}}$ is defined as the ratio of the vertical stability and the vertical shear of the horizontal wind:

$$
R i_{\mathrm{B}}=\frac{g}{\overline{\theta_{\mathrm{v}}}} \frac{\Delta \theta_{\mathrm{v}} \Delta z}{(\Delta u)^{2}+(\Delta v)^{2}},
$$

with $g$ the gravitational acceleration, $\theta_{\mathrm{v}}$ the virtual potential temperature, $z$ the altitude, and $u, v$ the horizontal wind components (Vogelezang and Holtslag, 1996). The differences $\Delta$ are obtained from the respective values at the surface and the layers above. $R i_{\mathrm{B}}$ provides an appropriate measure to characterise the stratification of the atmosphere and to determine the PBLH. The thermal stratification is determined from the sign of the bulk Richardson number. The flow is statically stable if $R i_{\mathrm{B}}$ is greater than zero, or else statically unstable or neutral. Furthermore, if $R i_{\mathrm{B}}$ is below a critical value, the flow will become dynamically unstable and marks the altitude between the turbulent boundary layer and the stable stratified free troposphere. We used a threshold value of $R i_{\mathrm{B}}=0.38$ which distinguish between a turbulent (low values of $R i_{\mathrm{B}}$ ) and a stable (large values of $R i_{\mathrm{B}}$ ) boundary layer. The same value is also used in the mesoscale model that we will introduce later (Fay, 1998). For clarity, the threshold value has been varied between 0.2 and 0.5 following suggestions from Zilitinkevich and Baklanov (2002) and Zhang et al. (2014), however, with a negligible effect on the results.

The PBLH has further been determined with the ceilometer, following the approach from Schneider and Eixmann (2002), to observe the height of the aerosol layer more frequently than with the radio soundings. The method is based on iterative averaging of the backscatter profile. Once the mean value has decreased to half the maximum average value inside the PBL, this altitude is designated to be the PBLH. Additionally, the height of the residual layer can be determined with this method at night. For our analysis we excluded all backscatter profiles which were observed during cloudy conditions. The determined boundary layers of the remaining backscatter profiles are averaged on an hourly basis.

\subsection{Lagrangian air mass analysis}

For the surface observations $24 \mathrm{~h}$ backward trajectories were calculated using LAGRANTO (Wernli and Davies, 1997; Sprenger and Wernli, 2015) from the position of Mount Kleiner Feldberg at $200 \mathrm{~m}$ above surface level (approximately between the modelled and actual mountain height) at 12:00 UTC for each day of the campaign. For the aircraft observations $24 \mathrm{~h}$ backward trajectories were calculated every $10 \mathrm{~s}$ along the flight path for each individual flight using LAGRANTO. In both cases, the trajectories were driven by model wind fields from the COSMO-7 analysis (Doms, 2011; Doms et al., 2011), operated by Swiss National Weather Service (MeteoSwiss). The meteorological fields from COSMO-7 are available every hour, the horizontal resolution is about $7 \mathrm{~km}$, and 61 vertical levels are used from the surface up to $20 \mathrm{hPa}$. The trajectories are calculated 


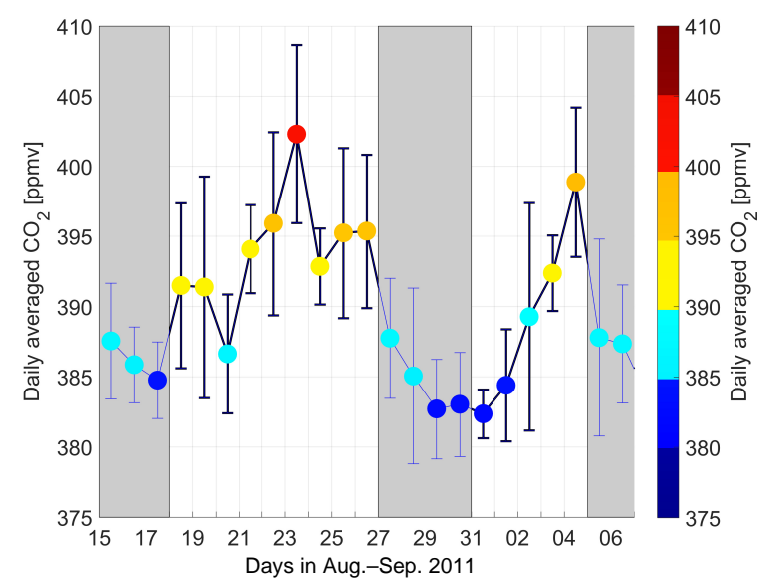

Figure 2. Daily averaged $\mathrm{CO}_{2}$ observations and the associated standard deviation during the measurement campaign parade on the Mount Kleiner Feldberg. The shaded areas indicate periods of highpressure influence (white) and low-pressure influence (grey).

from the three-dimensional, kinematic wind field, not taking into account additional parametrisations for convection or turbulence.

\subsection{Synoptic conditions during PARADE 2011}

The synoptic conditions were alternating mainly between two kinds of weather patterns. Prior to the start of the measurement period (15-18 August 2011) the situation was dominated by a low pressure system over northwestern Europe and a high pressure system over central Europe. On $19 \mathrm{Au}-$ gust 2011 a cold front related to a low pressure system over the north sea passed over the measurement area. This was then followed by high pressure conditions over central Europe (20-26 August 2011) with very warm and humid temperatures. This period was again succeeded by the passage of a low pressure system late in the day on 26 August 2011 which formed over the eastern Atlantic. This led to relatively low temperatures with $T_{\max }<14^{\circ} \mathrm{C}$ and continued until the end of August (31 August 2011). Similar conditions were found during the last days of the campaign, only interrupted by fair weather between the end of August and 4 September 2011.

This synoptic pattern is well reflected by the daily mean carbon dioxide $\left(\mathrm{CO}_{2}\right)$ mixing ratio observed at the surface for the entire campaign (Fig. 2). $\mathrm{CO}_{2}$ showed larger values during high pressure conditions (grey area), while lower $\mathrm{CO}_{2}$ values were observed during low pressure conditions (white area). Figure 3 shows that the near-surface based LAGRANTO backward trajectories match well with these synoptic conditions. Clean air masses from the north-west to westerly direction over the North Atlantic are linked to low $\mathrm{CO}_{2}$ mixing ratios, while enhanced $\mathrm{CO}_{2}$ values are related to the potentially polluted continental regions in southerly wind directions or related to local fair weather conditions. Note

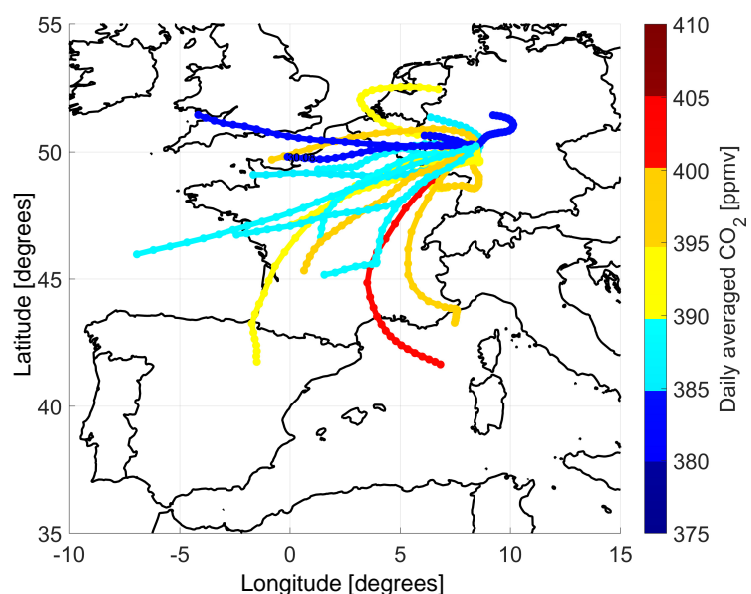

Figure 3. Backward trajectories, starting from the Mount Kleiner Feldberg at $200 \mathrm{~m}$ altitude over the surface for each day at 12:00 UTC up to $24 \mathrm{~h}$ based on wind fields from COSMO-7. The colours represent the daily averages of $\mathrm{CO}_{2}$ measurements from Mount Kleiner Feldberg (Fig. 2).

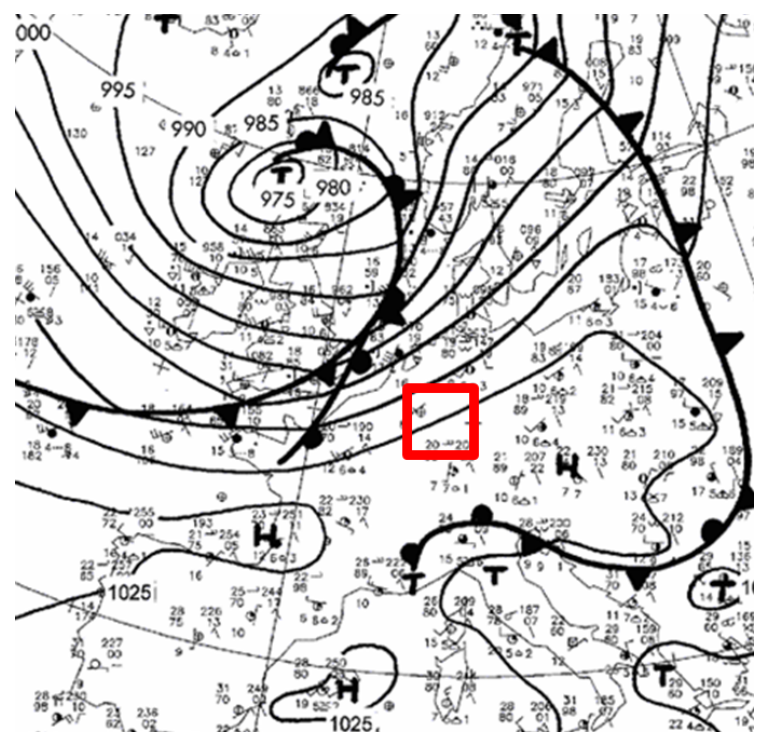

Figure 4. Surface pressure chart provided by the German Weather Service (DWD) over Europe on 6 September 2011, 12:00 UTC. The red box indicates the measurement area.

that biogenic uptake of $\mathrm{CO}_{2}$ through photosynthesis was of minor importance at the end of the European growing season and that the $\mathrm{CO}_{2}$ flux was probably dominated by anthropogenic emissions (Rivier et al., 2010).

\section{Results}

\subsection{Synoptic situation on 6 September 2011}

In the following we focus on one particular day (6 September 2011) when two research flights were completed. The two 


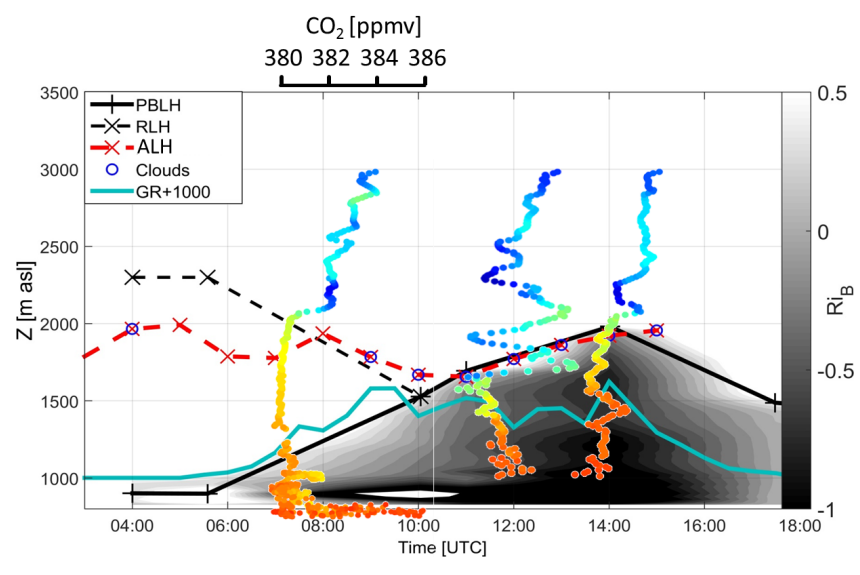

Figure 5. Diurnal variation of the residual layer height (RLH) and planetary boundary layer height (PBLH) derived from radiosondes (black) and ceilometer (red, hourly averaged). The distinction between the turbulent boundary layer and the stable FT is shown by the bulk Richardson number $R i_{\mathrm{B}}$ (grey scale). RLH is derived from the radiosonde temperature profiles (black dashed) and from $1 \mathrm{hr}$ averaged aerosol layer heights (AHL) calculated from the ceilometer backscatter profiles (red dashed). Blue circles indicate the occurrence of clouds during that day. The global radiation (GR, blue line) is provided from HLUG in $\mathrm{Wm}^{-2}$. Vertical profiles of $\mathrm{CO}_{2}$ are shown for different aircraft flights over Mount Kleiner Feldberg during this day in rainbow colours; for details see Figs. 7 and 8.

flights were flown in a prefrontal high pressure zone with a cyclonic system in northern Europe and high pressure in the south (Fig. 4). The approaching frontal system was associated with high wind speeds over central Europe, carrying air masses rapidly from the Atlantic Ocean to central Europe. A first trough reached western Europe on 5 September 2011, and marked the beginning of a series of low pressure systems. The next low was already present over Britain and Ireland. Its cold front was semi-occluded with the prefrontal warm front. Part of this warm front was situated over north-western France (Fig. 4). The strong westerly wind transported colder air masses from the Atlantic Ocean and fostered the evolution of small-scale convective cells.

\subsection{Diurnal evolution of the boundary layer on 6 September 2011}

In this section, we briefly discuss the diurnal evolution of the PBL on 6 September 2011. We show the temporal evolution of $R i_{\mathrm{B}}$ over Mount Kleiner Feldberg (Fig. 5). The vertical profiles of $R i_{\mathrm{B}}$ have been calculated solely from the radio soundings and were linearly interpolated between each profile in this figure. In the morning hours low values of $R i_{\mathrm{B}}$ are confined to the lowest layers (so called stable boundary layer). The extent of these low values increases during the day up to 2000 ma.s.l. This reflects the growth of the PBL. In the morning hours a second inversion layer was indicated by the radiosounding profiles at around 2000-2500 ma.s.l.
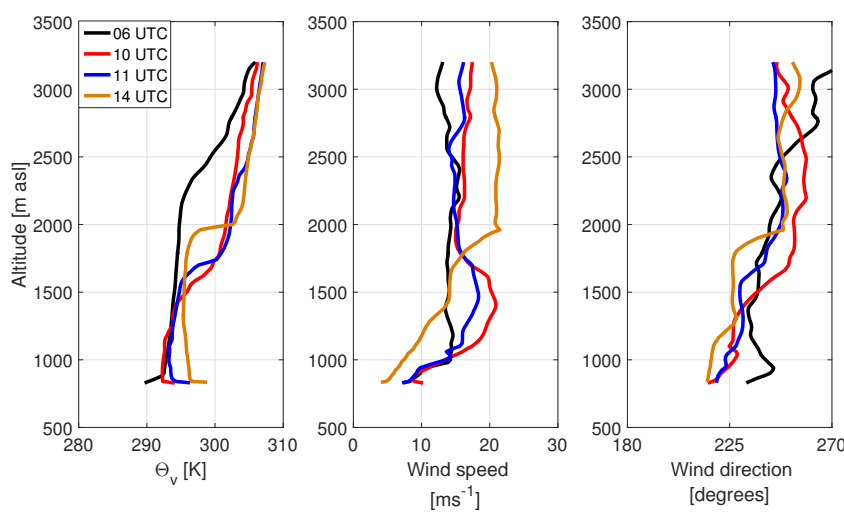

Figure 6. Profiles of (a) virtual potential temperature, (b) wind speed, and (c) wind direction derived from radiosondes during the day (black: 06:00 UTC, red: 10:00 UTC, blue: 11:00 UTC, orange: 14:00 UTC) on 6 September 2011.

This inversion further coincides with an increased backscatter signal detected by the ceilometer. The backscatter signal is related to an aerosol layer as well as the bottom of shallow cumulus clouds and marks the altitude of the residual layer.

The stable and residual layers merged between 10:00 and 11:00 UTC; afterwards only a single layered structure (now referred to as planetary boundary layer (PBL)) is detectable. Figure 6 shows profiles of the virtual potential temperature, wind speed and wind direction from the radio soundings just before and after the flights during that day. The PBLH at 11:00 UTC is located at $1640 \mathrm{ma}$ a.s.l. with an inversion strength of about $3 \mathrm{~K}$. The maximum PBLH of $1981 \mathrm{~m}$ a.s.1. occurred at 14:00 UTC, while the strengthening of the temperature inversion increased to about $10 \mathrm{~K}$. The wind direction within the PBL and FT was mostly constant during that day, whereas the wind speed increased within the FT and decreased within the PBL during the day. Later on, the PBLH decreased to about $500 \mathrm{~m}$ before the onset of precipitation at around 18:00 UTC (Fig. 5).

The air mass composition was probed twice during this day. The first flight took place between 07:00 and 09:30 UTC, while the second flight was between 11:00 and 14:00 UTC. Thus, a composition change of the PBL was expected from flight one to flight two, since the first flight took place before the two layers merged, while the second occurred after this event.

\subsection{Vertical profiles of trace gases during the boundary layer growth}

Figure 7 also shows $\mathrm{CO}_{2}$ profiles for the morning (07:27 UTC), noon (11:42 UTC) and afternoon (13:12 UTC). The profiles are colour-coded with specific humidity along the flight leg. The PBLH (black dashed line) and residual layer height (grey line), derived from the gradient of the 


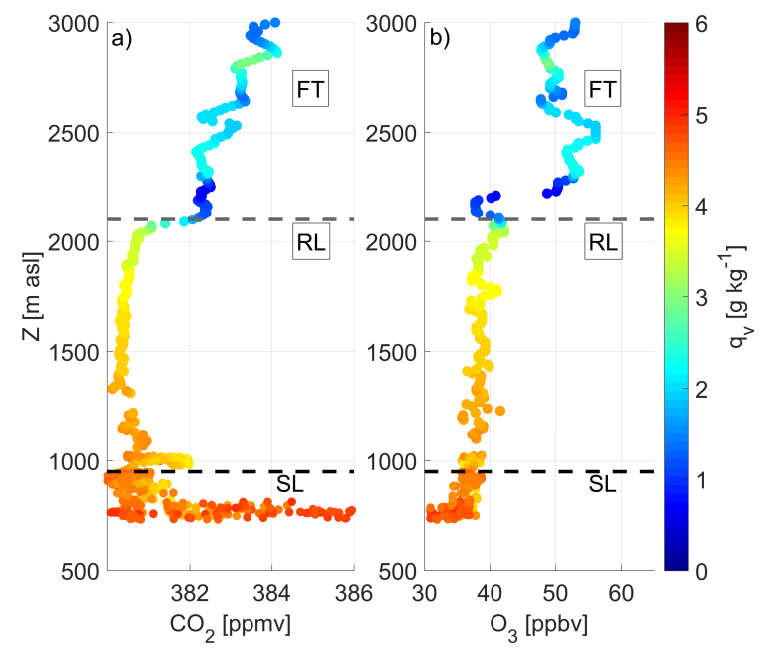

Figure 7. Vertical profiles of (a) $\mathrm{CO}_{2}$ and of (b) $\mathrm{O}_{3}$ in the morning (07:27 UTC) on 6 September 2011. The colour shows the specific humidity, and the horizontal lines show the boundary layer height (black dashed line) and the residual layer height (dashed grey line).

humidity profiles, correspond well to the derived boundary layer heights from the radiosonde measurements.

In the morning the vertical profiles of $\mathrm{CO}_{2}$ clearly show the three-layer structure of the PBL (Fig. 7a). Within the stable layer we observed a large variability of $\mathrm{CO}_{2}$ mixing ratios ranging between 380.0 and $394.3 \mathrm{ppmv}$ below $1000 \mathrm{~m}$ altitude. Between 1000 and 2300 ma.s.l. the vertical profile of $\mathrm{CO}_{2}$ in the residual layer was almost constant with mean values $\left(\overline{\mathrm{CO}_{2}}\right)$ of $380.5( \pm 0.16)$ ppmv, indicating that the residual layer was well mixed. A strong $\mathrm{CO}_{2}$ gradient at 2300 ma.s.l. reveals a sharp separation between the PBL and the FT which has a mean $\mathrm{CO}_{2}$ of about $383.0( \pm 0.58)$ ppmv). In the afternoon (13:12 UTC) $\mathrm{CO}_{2}$ is again well mixed within the PBL with $\overline{\mathrm{CO}_{2}}=$ $382.1( \pm 0.35)$ ppmv (see Fig. 5). A clear separation to the FT is evident again, with mean FT- $\mathrm{CO}_{2}$ mixing ratios of 383.7 ( \pm 0.38$)$ ppmv).

The transition period between the measurements of these two profiles is characterised by a much more variable $\mathrm{CO}_{2}$ profile, especially above the PBLH (Fig. 7b). $\mathrm{CO}_{2}$ decreases within the PBL with a mean value of $382.9( \pm 0.49)$ ppmv. Above 1500 ma.s.l. in the FT mean $\mathrm{CO}_{2}$ mixing ratios show a double peaked structure with maximum values of almost 386 ppmv and minimum values of 382 ppmv. Thus, a large variability with altitude is evident. Above $2300 \mathrm{~m}$ a.s.l. $\mathrm{CO}_{2}$ mixing ratios are more comparable again to mixing ratios observed in the morning and the afternoon with a mean value of $383.9( \pm 0.61)$ ppmv.

The vertical profiles of $\mathrm{O}_{3}$ show a similar temporal evolution development (Figs. 7 and 8). Largest $\mathrm{O}_{3}$ values are found in the FT above the boundary layer throughout the day and exceed local PBL values by typically 10 ppbv. The only exception is the transition period at 11:42 UTC, when $\mathrm{O}_{3}$ shows

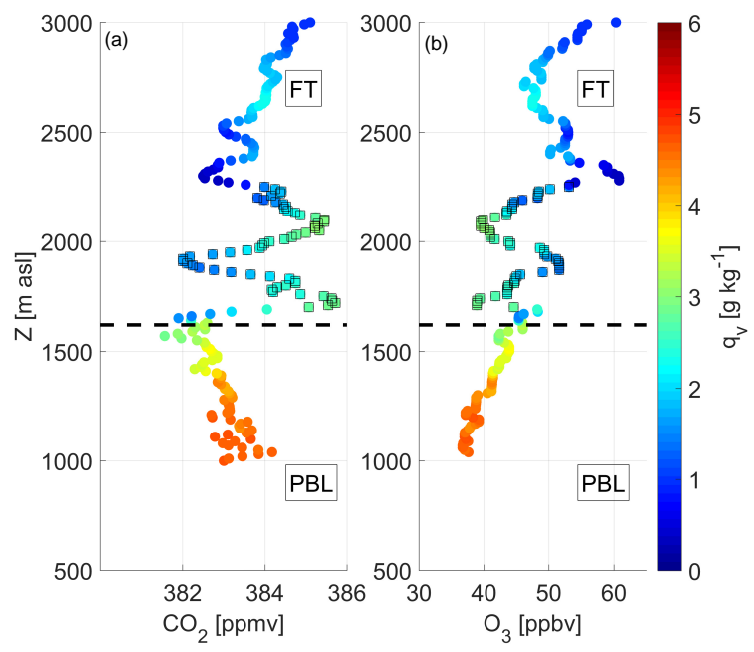

Figure 8. Same as Fig. 7 at noon. The measurement points between 1640 and $2200 \mathrm{~m}$ a.s.l. are influenced by mixing from the PBL and the FT.

a large variability. As for $\mathrm{CO}_{2}$ a double peak structure is evident, however, the maxima and minima are anti-correlated between $\mathrm{CO}_{2}$ and $\mathrm{O}_{3}$. Furthermore, $\mathrm{O}_{3}$ minima and $\mathrm{CO}_{2}$ maxima show large values of water vapour mixing ratio $q_{\mathrm{v}}$. These values exceed the commonly measured humidity values (less than $2 \mathrm{~g} \mathrm{~kg}^{-1}$ ) in the FT. Since the aircraft was allowed only to operate in cloud-free conditions, the large humidity values were only observed within the PBL. We will now analyse in detail how this complex structure is related to the observed development of the boundary layer structure.

\subsection{Mixing deduced from correlations}

The vertical profiles of $\mathrm{O}_{3}$ and $\mathrm{CO}_{2}$ and their temporal evolution over the course of the day are used to study a potential mixing event on 6 September 2011 above Mount Kleiner Feldberg. For this we now apply tracer-tracer correlations (e.g. Fischer et al., 2000; Hoor, 2002). Figure 9 shows the scatter plot between $\mathrm{O}_{3}$ and $\mathrm{CO}_{2}$ in the morning (07:27 UTC). Using the moisture information and mean values of $\mathrm{CO}_{2}$ and $\mathrm{O}_{3}$ it is possible to identify two separated air masses. The air mass in the residual and stable layers has low $\mathrm{O}_{3}$ values and variable values of $\mathrm{CO}_{2}$ and $q_{\mathrm{v}}$. The air mass in the FT is rather characterised by larger values of $\mathrm{O}_{3}$, low values of $q_{\mathrm{v}}$ and less variability in $\mathrm{CO}_{2}$.

At 11:42 UTC the appearance of the scatter plot changes significantly (Fig. 10). The chemical characteristics of two different air masses still can be identified, of which one has the characteristics of a boundary layer air mass (larger values for $q_{\mathrm{v}}$ ) and one of an FT air mass (lower values of $q_{\mathrm{v}}$ ). However, the air mass in the FT now also shows a larger variability in $\mathrm{CO}_{2}$ which we see as an indication of a PBL air mass that has entered the FT. Moreover, the $\mathrm{O}_{3}$ mixing ratios 


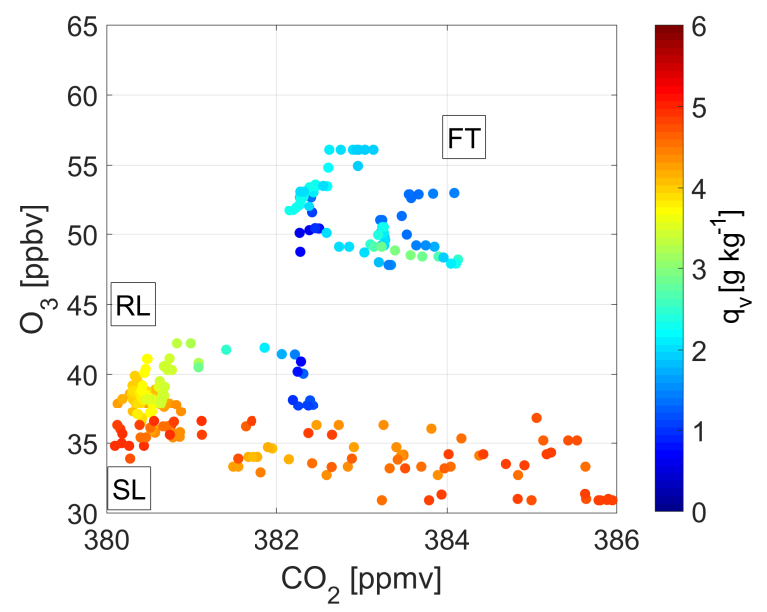

Figure 9. Correlations between $\mathrm{CO}_{2}$ and $\mathrm{O}_{3}$ during the observations at 07:27 UTC colour-coded according to specific humidity measurements. The aircraft descended from the FT into the PBL, indicated by a clear separation from the chemical signature.

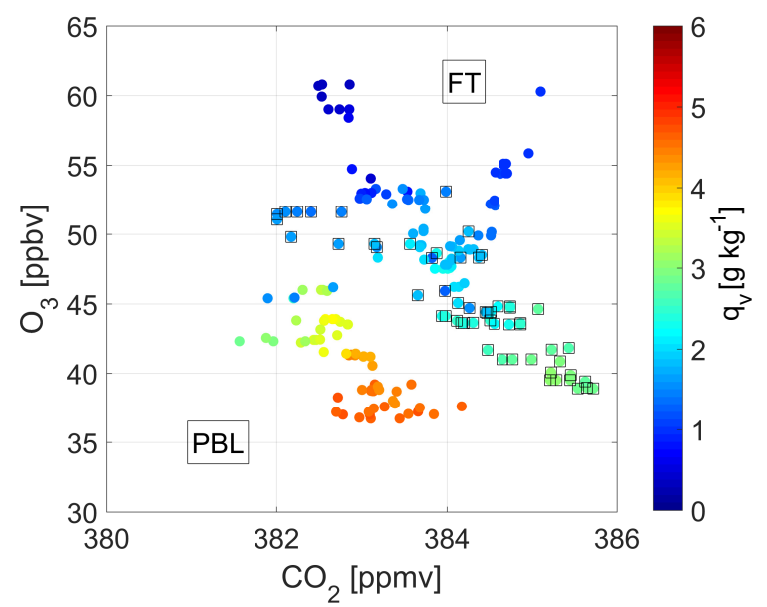

Figure 10. Same as Fig. 9 at noon. The measurement points between 1640 and $2200 \mathrm{ma}$ a.s.l. (black boxes) are related due to the mixed air masses from the stable layer and the FT.

in the PBL are also slightly increased which could be related to downward transport of a FT air mass.

Using now also the temporal and spatial information of the measured data points, a linear relationship between the FT and PBL air masses in the tracer-tracer scatter plot becomes evident (Fig. 10). This line is highlighted with the black boxes. These data points have been measured consecutively in an altitude range between 1640 and $2200 \mathrm{~m}$, which is just above the PBLH at 11:42 UTC (Fig. 5). The EZ was situated at this location and time. Thus we regard these data points as the result of mixing, and the observed linear tracertracer relationship as mixing line, since it relates to the evolution of the boundary layer structure during this day. The specific humidity of this mixing line shows a slightly larger variability than the variability of the FT background (Fig. 8).
This further supports our hypothesis of measuring a rather fresh mixing event. Note further that during this time clouds were present in the observation area with the cloud tops at around $2400 \mathrm{~m}$ a.s.l., according to the on-board observations and a post-flight analysis of photos taken during the flight. However, the strong variations of ozone, moisture and $\mathrm{CO}_{2}$ for the profile at 11:42 UTC (Fig. 7) have been observed exclusively in-between clouds.

In short, we identify local mixing between air masses from the PBL and the FT from the results of the tracer-tracer correlation technique for the trace gases $\mathrm{CO}_{2}$ and $\mathrm{O}_{3}$. Additionally, this mixing is supported by a larger variability of the specific humidity within the mixing region. In the following subsections, we will discuss processes which might have contributed to this mixing event as well as if this mixing event was influenced by long-range transport.

\section{Discussion}

\subsection{Impact of long-range transport?}

The origin of the probed air masses is investigated with $24 \mathrm{~h}$ kinematic backward trajectories using LAGRANTO (see Sect. 2.4) for this 1-day period. Figure 11 shows the zonal position of the backward trajectories along the flight path at release time $(0 \mathrm{~h}),-12$ and $-24 \mathrm{~h}$ prior to the measurements. Additionally, the trajectories are colour-coded with the ozone mixing ratio as measured onboard the aircraft. Ozone was chosen, as tracer in this figure, because of its strong vertical gradient. The ozone mixing ratio is averaged for the trajectory positions backward in time for each hour in bins of $0.5^{\circ}$ longitude and $250 \mathrm{~m}$ altitude. The binning compromises all calculated trajectories and reflects the transport of air for a time period $24 \mathrm{~h}$ before the observations for the second flight around noon. It is evident that the measurement region has been influenced by air masses from two different origins (Fig. 11). The trajectory analysis reveals that the air mass probed above $2000 \mathrm{~m}$ with large $\mathrm{O}_{3}$ mixing ratios has been transported rapidly from westerly directions towards the measurement site. Furthermore, only these trajectories reside within the $\mathrm{FT}$ with the high $\mathrm{O}_{3}$ mixing ratios. The trajectories at lower levels indicate that the air mass at this altitude range with low $\mathrm{O}_{3}$ mixing ratios has been advected more slowly. Importantly, air masses initialised below $2000 \mathrm{~m}$, thus mainly within the turbulent boundary layer, show a larger spread of the trajectories and tend to stay in the boundary layer corresponding to low ozone mixing ratios. A similar behaviour is evident from $\mathrm{CO}_{2}$ (not shown) confirming a clear separation between free tropospheric and boundary layer transport.

We conclude that the entrainment zone separates ozonerich air masses, which were transported in the free troposphere with higher wind speed than from air masses, which resided in the boundary layer with lower wind speed, as indicated by the low ozone mixing ratios. The clear vertical 

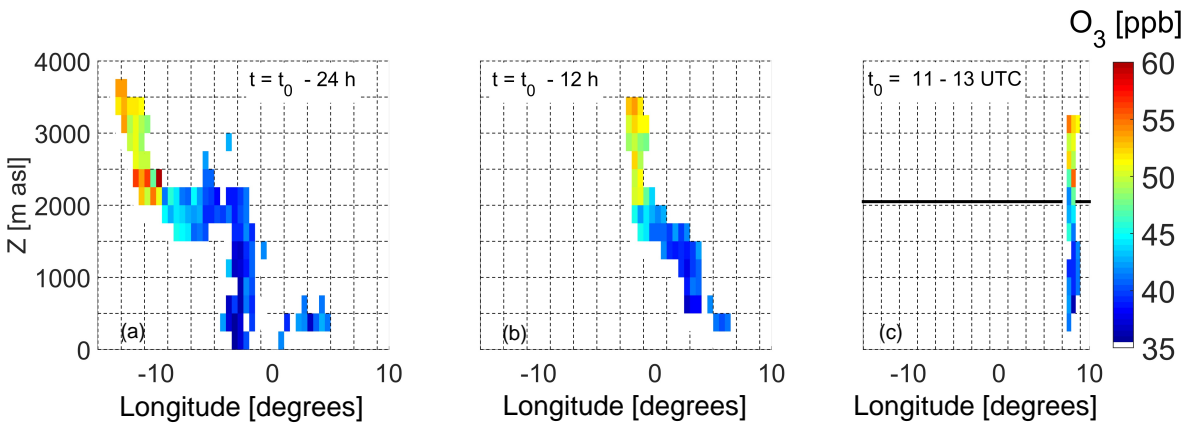

Figure 11. Temporal evolution of air mass origins between 11:00 and 13:00 UTC on 6 September 2011. The trajectory positions are colour coded by mixing ratios of ozone as measured along the flight leg. The data are binned by $0.5^{\circ}$ longitude and $250 \mathrm{~m}$ altitude (for details see text). The black line marks the maximum PBLH during that time.

separation of air masses between the FT and PBL is therefore reflected by the different chemical signature of the air masses and is an indication that the two respective air masses were spatially separated. It is thus an indication that the air masses must have been mixed shortly before or at the measurement location.

\subsection{Impact of the local boundary layer conditions and cloud development}

We will now show whether local mixing between boundary layer air and the air in the free troposphere can explain the observed signatures of mixing. The PBLH reaches 1640 ma.s.l. with an inversion strength of $3 \mathrm{~K}$ at 11:00 UTC. The residual layer height in the morning, as identified from the ceilometer and secondary temperature inversions from the radio soundings, reaches $2100 \mathrm{~m}$. From 11:42 to 13:12 UTC the PBLH grew to 2000 ma.s.l. and reaches a temperature inversion strength of $8-10 \mathrm{~K}$. On the one hand, the growth of the boundary layer since 11:42 UTC is an indication for further entrainment of the overlying air masses into the PBL, which leads to further mixing. On the other hand, the increase of the inversion strength limits the entrainment from air above and also the upward transport to the FT and reduced mixing (Angevine, 2007).

As shown in Fig. 5 the boundary layer top during the measurements was affected by the occurrence of clouds. These clouds were aligned along straight lines (Fig. 12), which is also evident from satellite images (not shown). The presence of clouds can affect the strength of the inversion layer as well as of the mixing between PBL and FT. Stevens (2007) and Malinowski et al. (2011) showed that radiative cooling at the upper edge of the clouds promotes a downward mixing of air and thus influences the inversion strength and might also contribute to the observed mixing event by entrainment of dry air from the FT. This can be seen by the decrease of the mean specific humidity between 1640 and 2200 ma.s.l. from the morning $\left(\overline{q_{\mathrm{v}}}=2.8( \pm 1.2) \mathrm{g} \mathrm{kg}^{-1}\right)$ to noon time $\left(\overline{q_{\mathrm{v}}}=2.1( \pm 0.7) \mathrm{g} \mathrm{kg}^{-1}\right)$.

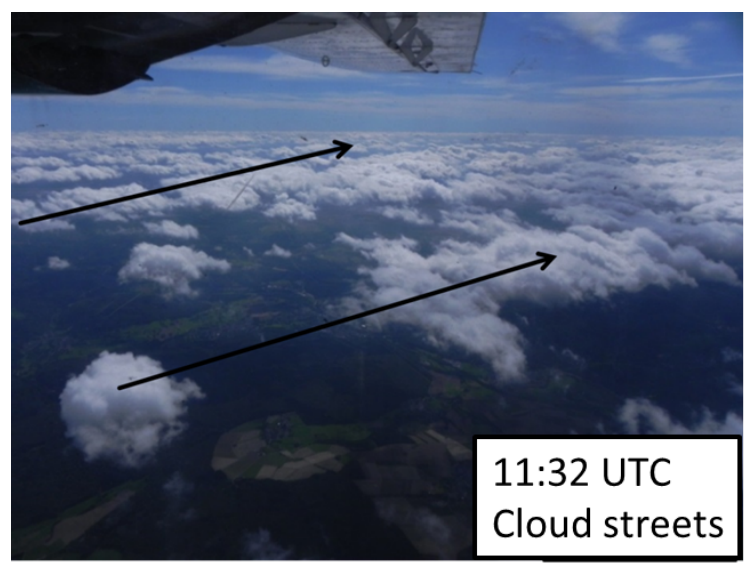

Figure 12. Cloud formation below the flight track at about 11:32 UTC. Just before measuring a profile by descending above Mount Kleiner Feldberg. The arrows show the mean wind direction.

An important feature of these cloud structures is the formation of roll vortices, which are aligned along the axis of the cloud bands. The cloud bands can be regarded as an indicator of shallow convection within the boundary layer. Moist air is lifted from near the surface up to the top of the PBL where the clouds form and the air descends in-between the clouds. The indicated air motion contributes especially to a further mixing of the PBL air mass, but can also increase the mixing potential between the PBL and the FT. This can then result in the vertical profiles of $\mathrm{CO}_{2}$ as observed between the morning and the afternoon on 6 September 2011 (see Fig. 6). Hägeli et al. (2000) observed similar relationships for temperature and for moisture profiles within the cloud free area between the cloud streets. It should be noted that many experimental studies are restricted to cloud-free conditions as summarised by Kalthoff et al. (2013).

So we suggest that the mixing event is linked to the evolution of shallow convection and consecutive cloud formation at the top of the PBL. Therefore, we will discuss the three $\mathrm{CO}_{2}$ profiles during this day (Fig. 7), which reflect the sus- 
pected dynamic processes from theoretical approaches (e.g. Etling and Brown, 1993; Lock et al., 2000; Stevens et al., 2003).

As shown by Ouwersloot et al. (2013), shallow cumulus clouds play a major role for the mass flux and associated tracer fluxes when analysing vertical transport of tracers, since they might dominate vertical mass flux. Over the course of the day the cloud fraction increased from clear sky to $100 \%$ and constituted shallow cumulus clouds until noon. According to the ceilometer data and the soundings the aerosol and boundary layer height changed from 1000 to $1640 \mathrm{~m}$ a.s.l. between 07:30 UTC and the second flight at 11:45 UTC, along with the cloud cover, which is reflected by the decrease of the global radiation in Fig. 5. If we assume absence of chemical loss and production for the tracers, an upward mass flux would lead to an enhancement of $\mathrm{CO}_{2}$ from the nocturnal accumulation close to the surface accompanied by a decrease of ozone in the ascending branch of the subcloud layer. Such an upward mass flux would lead to tracer contrasts between the in-cloud and out-cloud region as well as between the in-cloud and downward mixing region. As indicated by structured $\mathrm{CO}_{2}$ and profiles where the $\mathrm{CO}_{2}$ maxima are accompanied by high specific humidity, a cloud-induced upward mass flux fits the observations of these peaks. In contrast the minima can be related to both the free tropospheric tracer composition of ozone, $\mathrm{CO}_{2}$ and humidity. Based on these gradients we estimated the entrainment velocity and the mass flux (expressed as velocity) according to Eqs. (5) and (6) by Ouwersloot et al. (2013). We find that the entrainment velocity $\left(0.25 \mathrm{~m} \mathrm{~s}^{-1}\right)$ is strongly increased by a cloud-induced upward mass flux. Not accounting for the mass flux the entrainment velocity would be about $50 \%$ lower in the case of the $\mathrm{CO}_{2}$ budget. The largest uncertainties arise from the missing measurements of the surface fluxes and the estimates within the cloud layer, which was not penetrated from the aircraft.

As discussed before (Figs. 5 and 7), in the afternoon (11:42 UTC) the $\mathrm{CO}_{2}$ profiles between 1600 and $2300 \mathrm{~m}$ show double peak $\mathrm{CO}_{2}$-mixing ratios around $\sim 386 \mathrm{ppmv}$, which were only present near the surface in the morning. Since there are no significant sources or sinks of $\mathrm{CO}_{2}$ in the FT, these enhanced values indicate that surface air has been lifted locally and remains at this altitude when the cloud dissolved (Vila-Guerau de Arellano, 2005). This is also the case for specific humidity and ozone at this height, which exhibit exactly the same air mass composition as previously observed at the surface.

In principle, high ozone values can also be the result of photochemical ozone production, but ozone production would not add more than a few ppb per day (Morris et al., 2010). Ouwersloot et al. (2013) showed that ozone can be influenced by UV radiation extinction by clouds and atmospheric compounds like $\mathrm{NO}$ and $\mathrm{NO}_{2}$. However, the high ozone values are accompanied by low humidity, which indicates potential downward transport from higher altitudes.
This is confirmed by 5-day backward trajectories (calculated with ECMWF analysis $\left(0.5^{\circ} \mathrm{C}\right.$ horizontal resolution, 90 vertical layer, $3 \mathrm{~h}$ time resolution)), which show that these air masses reached a maximum height of about $6 \mathrm{~km}$ over the Atlantic Ocean, without any surface contact (not shown). Finally, during the entire day the specific humidity in the free troposphere showed very low mean values of $1.4-2.0 \mathrm{~g} \mathrm{~kg}^{-1}$. This indicates that the free troposphere was dominated by an air mass of similar chemical characteristics during the measurements on 6 September 2011. Between 2200 and $2500 \mathrm{~m}$ a.s.l. the ozone-rich air mass is also observed with larger humidity. The variations of $\mathrm{O}_{3}, \mathrm{CO}_{2}$ and $q_{\mathrm{v}}$ above $2000 \mathrm{~m}$ clearly indicate layers of different origin in the region between 1600 and $2300 \mathrm{~m}$ a.s.l. in the cloud interstitial regions between the roll clouds.

Therefore, the growth of the PBL is an indication of entrainment from the FT into the PBL. On the other hand the increase of the temperature inversion (cause from large-scale subsidence) provides strengthening of the inversion layer and limited the further boundary layer growth, but entrainment still occurs (Ouwersloot et al., 2013).

\subsection{Impact of mixing on surface measurements}

It has previously been shown that boundary layer air trapped within the stable layer can suddenly be mixed in the newly growing PBL as soon as the PBL becomes unstable (Stull, 1988). In addition, large-scale synoptic situations can lift these air masses out of the PBL into the FT (Sinclair et al., 2010). Vice versa, polluted plumes from the FT can enter the PBL by downward mixing and potentially lead to an increase of the pollution levels near the surface in initially clean regions (McKendry and Lundgren, 2000; Neuman et al., 2012).

Figure 13 shows the ozone mixing ratios onboard the aircraft and the time series at the surface. The airborne measurements below 800 ma.s.l. agree well with the surface observations of about $30 \mathrm{ppb}$. The higher values around 07:30 UTC observed onboard the aircraft can be explained by the fact that the measurements directly at the surface are affected by deposition and ozone loss processes within the stable nocturnal boundary layer, which was not accessible for the aircraft. As shown in Fig. 5, around 09:00 UTC at the end of the first flight the stable layer of the lowest level disappears and is then mixed with the newly growing boundary layer. At this time, between the two flights, there occurs an increase of $\mathrm{O}_{3}$ of $6 \mathrm{ppbvh}^{-1}$ up to a maximum mixing ratio of $43 \mathrm{ppbv}$ at noon. The increase of ozone can be attributed to photochemical ozone production and downward mixing from the free troposphere. McKendry and Lundgren (2000) showed that an increase of the ozone mixing ratio larger than $5 \mathrm{ppbv}^{-1}$ has been related to downward transport from the FT and not to photochemical production alone. As mentioned earlier, clouds formed initially between 09:00 and 10:00 UTC. For that reason the global radiation decreased and hence the photochemical ozone production efficiency reduced (Fig. 5). 


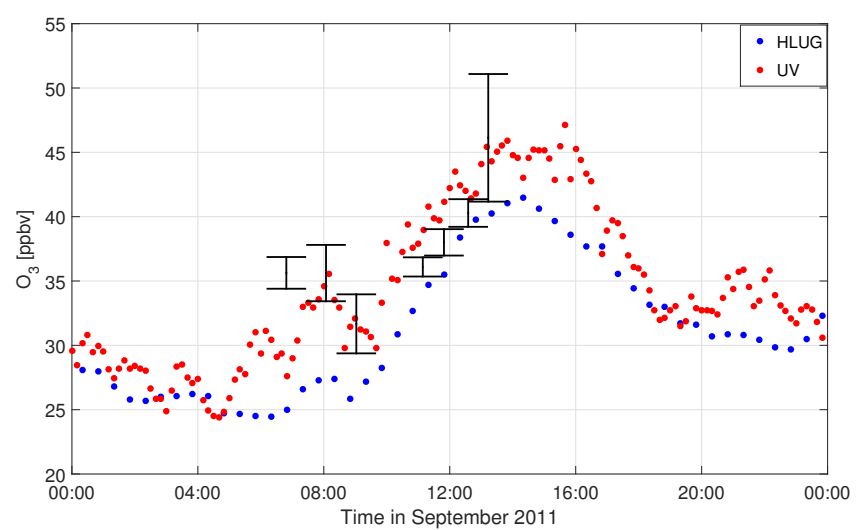

Figure 13. Surface ozone measurements of different instruments at different inlets (HLUG (blue, 30 min mean) and UV absorption (red, 10 min mean)) on Mount Kleiner Feldberg (825 ma.s.1.), including the aircraft observations (mean and standard deviation between 1000 to 1600 ma.s.1.) on 6 September 2011.

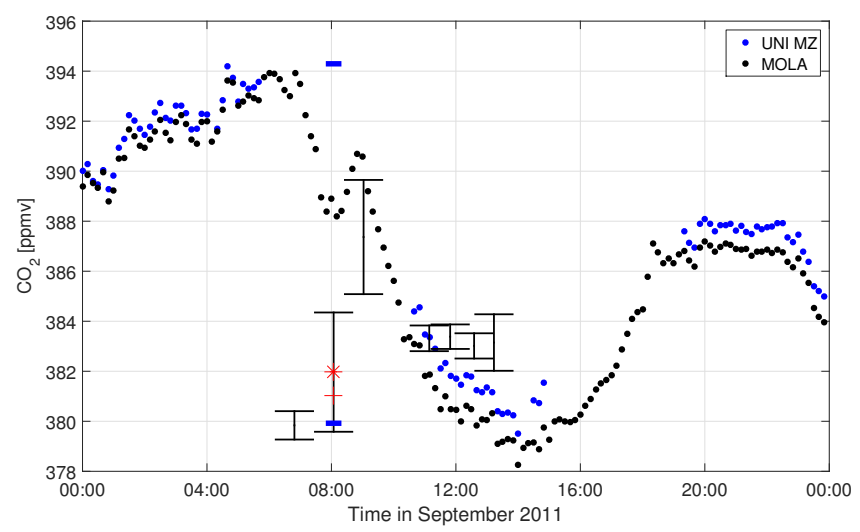

Figure 14. $\mathrm{CO}_{2}$ surface measurements (on Mount Kleiner Feldberg (825 ma.s.1.), see Sect. 2.2), including the aircraft observations (mean and standard deviation between 1000 to $1600 \mathrm{~m}$ a.s.1.) on 6 September 2011. The high $\mathrm{CO}_{2}$ fluctuations at 08:00 UTC are demonstrated by the mean (red star), standard deviation (black error bars), median (red bar) and maximum/minimum values (blue bar).

Figure 14 shows the $\mathrm{CO}_{2}$ mixing ratio onboard the aircraft and near the surface. The airborne $\mathrm{CO}_{2}$ measurements show low mixing ratios of $381 \mathrm{ppmv}$ (08:00 UTC) compared to the high $\mathrm{CO}_{2}$ surface measurements. This large difference is due to accumulated $\mathrm{CO}_{2}$ in the stable boundary layer during night. This is consistent with slightly enhanced ozone measured onboard the aircraft for this period (see Fig. 13). The aircraft was always flying at least $100 \mathrm{~m}$ above the surface where the $\mathrm{CO}_{2}$ values are already much lower compared to the stable surface layer below. Note that the $\mathrm{CO}_{2}$ profile in Fig. 5 also indicates much higher $\mathrm{CO}_{2}$ values at the lowest levels, which are in the same range as observed at the surface at Mount Kleiner Feldberg. Thus during night, $\mathrm{CO}_{2}$ at the surface is dominated by plant respiration and anthropogenic $\mathrm{CO}_{2}$ emissions. During day a potential effect from downward mixing at the surface is probably masked by some local uptake of $\mathrm{CO}_{2}$ by vegetation.

The particle number concentration measurements show very low values of $1-2$ particles $\mathrm{ccm}^{-1}$ within the FT. Within the PBL we observe a larger particle number concentration from the CPC (210 particles $\left.\mathrm{ccm}^{-1}\right)$ than from the OPC (40 particles $\mathrm{ccm}^{-1}$ ). Since the measurement site is covered by cumulus clouds (see Fig. 4), it is obvious that particles larger than $100 \mathrm{~nm}$ were activated to form cloud droplets. These measurements could not be used to further support the mixing process. Furthermore, the backscatter signal from the ceilometer was mostly affected by the clouds (after 10:00 UTC) and therefore we observed only the cloud base height. The increase of $\mathrm{O}_{3}$ near the surface is most likely the result of mixing of $\mathrm{O}_{3}$-rich air masses from the FT. This downward transport process would match well with the time of occurrence of the mixing line.

\section{Conclusions}

Extensive surface-based, balloon-based and airborne measurements were collected as part of the measurement campaign PARADE on Mount Kleiner Feldberg $(825 \mathrm{~m})$ in summer 2011. We used these data to investigate the diurnal evolution of the boundary layer height over this complex terrain as well as the potential impact of local and long-range transport of trace gases. Our focus was on two research flights on 6 September 2011 where vertical tracer properties of $\mathrm{CO}_{2}$ and $\mathrm{O}_{3}$ indicated the occurrence of mixing across the entrainment zone. The planetary boundary layer height was determined using the bulk Richardson number $\left(R i_{\mathrm{B}}\right)$ from measurements taken from radio soundings. This approach can be used both under stable and unstable conditions using the same criteria. The boundary layer top grew from $860 \mathrm{~m}$ a.s.l. in the morning up to $2000 \mathrm{ma}$ a.s.l. in the afternoon. During this growth it merged with the residual layer $(2100 \mathrm{~m}$ a.s.l. at 06:00 UTC). Negative $R i_{\mathrm{B}}$ values indicated that the PBL is convectively driven and turbulent during that day, and thus well mixed. Additionally, airborne measurements of various trace gases $\left(\mathrm{CO}_{2}\right.$ and $\left.\mathrm{O}_{3}\right)$ and particle number concentrations were performed in cloud-free areas during that day.

The temporal evolution of the measured vertical trace gas profiles showed the evolution of the PBL as observed with the radio soundings. The merging of the stable boundary layer, residual layer and free troposphere with the convective driven boundary layer is involved with mixing of the trace gases from these different atmospheric layers, and leads to complex vertical profiles of the trace gases. The tracer-tracer correlations have been applied to identify this mixing event and the effect on the trace gas distribution change across the transport barrier at the boundary layer top. This mixing line is probably formed by vertical uplift of $\mathrm{CO}_{2}$-rich and $\mathrm{O}_{3}$ poor air masses from the morning stable boundary layer. The strong western wind transported cold air masses from the At- 
lantic Ocean and caused the development of cloud streets. The structure of the trace gas profiles resembles the vertical cloud structure. We found the mixed air masses in the cloud interstitial space. This is consistent with convective uplifting and mixing with FT air at the cloud top within the clouds and subsidence of outside the clouds. It is suggested that these conditions forced mixing between the FT and the PBL. It cannot be excluded that the mixing event was affected by long-range transport. The analysis of the local meteorological situation and the trace gas observations, however, provide strong evidence that the local boundary layer growth leads to mixing at the PBL top. This is supported by the specific humidity, which shows on the mixing line a slightly larger variability than the variability of the FT background humidity. The additional formation of shallow convective clouds at the PBL top (and roll convection) probably led to an efficient exchange between the boundary layer and the free troposphere.

We conclude that rapid boundary layer growth and its interaction with convective clouds at the PBL top can efficiently mix both air masses and lead to variability that can be characterised by mixing lines. Moreover, the analysis of mixing lines provides a powerful tool to identify the occurrence and the effect of processes, which lead to a constituent exchange and mixing across the inversion layer.

\section{The Supplement related to this article is available online at doi:10.5194/acp-16-6011-2016-supplement.}

Acknowledgements. The authors are grateful to all PARADE members making this field campaign successful, and especially thank John Crowley for organising it. We particularly thank Enviscope $\mathrm{GmbH}$ for the execution of the flights and their excellent support during the campaign. We acknowledge Ralf Weigel for providing the particle number concentrations measurements onboard the aircraft. Moreover, we thank Andreas Reiffs and Uwe Parchatka for providing the surface ozone measurements, and Johannes Fachinger for the surface $\mathrm{CO}_{2}$ observations from MoLa. Janina Wendling is acknowledged for analysis of the ceilometer measurements, and we would like to thank Szymon Malinowski for fruitful discussion. Furthermore, we acknowledge the German Weather Service (DWD), the Swiss National Weather Service (MeteoSwiss) and ECMWF for providing meteorological analysis during the field campaign. MODIS satellite images were obtained from rapid fire. This work was supported by the International Max Planck Research School (IMPRS) and the aircraft flights were founded by the MPIC. D. Kunkel acknowledges funding from the German Science Foundation under grant HO 4225/2-1. We would like to thank the two anonymous reviewers for their helpful comments.
The article processing charges for this open-access publication were covered by a Research Centre of the Helmholtz Association.

Edited by: G. Feingold

\section{References}

Angevine, W. M.: Transitional, entraining, cloudy, and coastal boundary layers, Acta Geophys., 56, 2-20, doi:10.2478/s11600007-0035-1, 2007.

Arya, S. P.: Introduction to Micrometeorology, vol. 79, 2nd edn., Academic Press, 2001.

Bange, J., Spieß, T., and van den Kroonenberg, A.: Characteristics of the early-morning shallow convective boundary layer from Helipod Flights during STINHO-2, Theor. Appl. Climatol., 90, 113-126, doi:10.1007/s00704-006-0272-2, 2007.

Beck, J. P., Asimakopoulos, N., Bazhanov, V., Bock, H. J., Chronopoulos, G., Muer, D. D., Ebel, A., Flatøy, F., Hass, H., van Haver, P., Hov, O., Jakobs, H. J., Kirchner, E. J. J., Kunz, H., Memmesheimer, M., van Pul, W. A. J., Speth, P., Trickl, T., and Varotsos, C.: Exchange of Ozone Between the Atmospheric Boundary Layer and the Free Troposphere, Springer-Verlag, doi:10.1007/978-3-642-58729-0_5, 1997.

Bonn, B., Bourtsoukidis, E., Sun, T. S., Bingemer, H., Rondo, L., Javed, U., Li, J., Axinte, R., Li, X., Brauers, T., Sonderfeld, H., Koppmann, R., Sogachev, A., Jacobi, S., and Spracklen, D. V.: The link between atmospheric radicals and newly formed particles at a spruce forest site in Germany, Atmos. Chem. Phys., 14, 10823-10843, doi:10.5194/acp-14-10823-2014, 2014.

Canut, G., Lothon, M., Saïd, F., and Lohou, F.: Observation of entrainment at the interface between monsoon flow and the Saharan Air Layer, Q. J. Roy. Meteor. Soc., 136, 34-46, doi:10.1002/qj.471, 2010.

Cohen, C.: A Quantitative investigation of entrainment and detrainment in numerically simulated cumulonimbus clouds, J. Atmos. Sci., 57, 1657-1674, doi:10.1175/15200469(2000)057<1657:AQIOEA>2.0.CO;2, 2000.

Cohn, S. A. and Angevine, W. M.: Boundary layer height and entrainment zone thickness measured by lidars and wind-profiling radars, J. Appl. Meteorol., 39, 1233-1247, doi:10.1175/15200450(2000)039<1233:BLHAEZ>2.0.CO;2, 2000.

Conzemius, R. J. and Fedorovich, E.: Dynamics of sheared convective boundary layer entrainment - Part I: Methodological background and large-eddy simulations, J. Atmos. Sci., 63, 11511178, doi:10.1175/JAS3691.1, 2006.

Cooper, O. R., Langford, A. O., Parrish, D. D., and Fahey, D. W.: Challenges of a lowered US ozone standard, Science, 6239, 1096-1097, doi:10.1126/science.aaa5748, 2015.

Crowley, J. N., Schuster, G., Pouvesle, N., Parchatka, U., Fischer, H., Bonn, B., Bingemer, H., and Lelieveld, J.: Nocturnal nitrogen oxides at a rural mountain-site in south-western Germany, Atmos. Chem. Phys., 10, 2795-2812, doi:10.5194/acp-10-27952010, 2010.

Doms, D.: A description of the nonhydrostatic regional COSMOmodel, Part I: Dynamics and numerics, Tech. rep., Deutscher Wetterdienst, 2011. 
Doms, D., Förstner, J., Heise, E., Herzog, H., Mironov, D., Raschendorfer, M., Reinhardt, T., Ritter, B., Schrodin, R., Schulz, J., and Vogel, G.: A description of the nonhydrostatic regional COSMOmodel, Part II: Physical parameterization, Tech. rep., Deutscher Wetterdienst, 2011.

Donnell, E. A., Fish, D. J., Dicks, E. M., and Thorpe, A. J.: Mechanisms for pollutant transport between the boundary layer and the free troposphere, J. Geophys. Res., 106, 7847, doi:10.1029/2000JD900730, 2001.

Drewnick, F., Böttger, T., von der Weiden-Reinmüller, S.-L., Zorn, S. R., Klimach, T., Schneider, J., and Borrmann, S.: Design of a mobile aerosol research laboratory and data processing tools for effective stationary and mobile field measurements, Atmos. Meas. Tech., 5, 1443-1457, doi:10.5194/amt-5-1443-2012, 2012.

Driedonks, A. and Tennekes, H.: Entrainment effects in the wellmixed atmospheric boundary layer, Bound.-Lay. Meteorol., 30, 75-105, doi:10.1007/978-94-009-6514-0_4, 1984.

Eresmaa, N., Karppinen, A., Joffre, S. M., Räsänen, J., and Talvitie, H.: Mixing height determination by ceilometer, Atmos. Chem. Phys., 6, 1485-1493, doi:10.5194/acp-6-1485-2006, 2006.

Etling, D. and Brown, R. A.: Roll vortices in the planetary boundary layer: A review, Bound.-Lay. Meteorol., 65, 215-248, doi:10.1007/BF00705527, 1993.

Fay, B.: Evaluation and intercomparison of mixing heights based on the new prognostic turbulence scheme of the pre-operational limited area model at the german weather service, Harmo5 Conference, Rhodes, Greece, 18-21 May, 1998.

Fischer, H., Wienhold, F. G., Hoor, P., Bujok, O., Schiller, C., Siegmund, P., Ambaum, M., Scheeren, H. A., and Lelieveld, J.: Tracer correlations in the northern high latitude lowermost stratosphere: Influence of cross-tropopause mass exchange, Geophys. Res. Lett., 27, 97-100, doi:10.1029/1999GL010879, 2000.

Flaty, F., Hov, O., and Smit, H.: Three-dimensional model studies of exchange processes of ozone in the troposphere over Europe, J. Geophys. Res., 100, 11465-11481, doi:10.1029/95JD00845, 1995.

Gurk, Ch., Fischer, H., Hoor, P., Lawrence, M. G., Lelieveld, J., and Wernli, H.: Airborne in-situ measurements of vertical, seasonal and latitudinal distributions of carbon dioxide over Europe, Atmos. Chem. Phys., 8, 6395-6403, doi:10.5194/acp-8-6395-2008, 2008.

Hägeli, P., Steyn, D. G., and Strawbridge, K. B.: Spatial and temporal variability of mixed-layer depth and entrainment zone thickness, Bound.-Lay. Meteorol., 96, 47-71, doi:10.1023/A:1002790424133, 2000.

Handisides, G. M.: The influence of peroxy radicals on ozone production, Dissertation, Johann Wolfgang Goethe University, Frankfurt a. M., 2001.

Hauf, T., Schulte, P., Alheit, R., and Schlager, H.: Rapid vertical trace gas transport by an isolated midlatitude thunderstorm, J. Geophys. Res., 100, 22957-22970, doi:10.1029/95JD02324, 1995.

Henne, S., Furger, M., Nyeki, S., Steinbacher, M., Neininger, B., de Wekker, S. F. J., Dommen, J., Spichtinger, N., Stohl, A., and Prévôt, A. S. H.: Quantification of topographic venting of boundary layer air to the free troposphere, Atmos. Chem. Phys., 4, 497509, doi:10.5194/acp-4-497-2004, 2004.
Henne, S., Dommen, J., Neininger, B., Reimann, S., Staehelin, J., and Prevot, A. S. H.: Influence of mountain venting in the Alps on the ozone chemistry of the lower free troposphere and the European pollution export, J. Geophys. Res.-Atmos., 110, D22307, doi:10.1029/2005JD005936, 2005.

Hoor, P.: Seasonal variations of a mixing layer in the lowermost stratosphere as identified by the CO-O 3 correlation from in situ measurements, J. Geophys. Res., 107, 4044, doi:10.1029/2000JD000289, 2002.

Hov, O. and Flatoy, F.: Convective redistribution of ozone and oxides of nitrogen in the troposphere over Europe in summer and fall, J. Atmos. Chem., 28, 319-337, doi:10.1023/A:1005780730600, 1997.

Jaffe, Dan: Relationship between surface and free tropospheric ozone in the Western US, Environ. Sci. Technol., 45, 432-438, doi:10.1021/es1028102, 2011.

Kalthoff, N., Träumner, K., Adler, B., Späth, S., Behrendt, A., Wieser, A., Handwerker, J., Madonna, F., and Wulfmeyer, V.: Dry and moist convection in the boundary layer over the Black Forest - a combined analysis of in situ and remote sensing data, Meteorol. Z., 22, 445-461, doi:10.1127/0941-2948/2013/0417, 2013.

Klein, H., Nickovic, S., Haunold, W., Bundke, U., Nillius, B., Ebert, M., Weinbruch, S., Schuetz, L., Levin, Z., Barrie, L. A., and Bingemer, H.: Saharan dust and ice nuclei over Central Europe, Atmos. Chem. Phys., 10, 10211-10221, doi:10.5194/acp10-10211-2010, 2010.

Köllner, F.: Charakterisierung und Einsatz eines flugzeuggetragenen Ozonmessgerätes in der Grenzschicht, Thesis, JohannesGutenberg Universität, Mainz, 2013.

Kossmann, M., Corsmeier, U., De Wekker, S. F., Fiedler, F., Vögtlin, R., Kalthoff, N., Güsten, H., and Neininger, B.: Observations of handover processes between the atmospheric boundary layer and the free troposphere over mountaineous terrain, Atmos. Phys., 72, 329-350, 1999.

Li, J., Reiffs, A., Parchatka, U., and Fischer, H.: In situ measurements of atmospheric $\mathrm{CO}$ and its correlation with $\mathrm{NO}_{x}$ and $\mathrm{O}_{3}$ at a rural mountain site, Metrol. Meas Syst., 22, 25-38, 2015.

Lilly, D. K.: Models cloud-topped mixed layers under a strong inversion, Tech. Rep. July 1967, 1968.

Lin, M., Fiore, A. M., Horowitz, L. W., Cooper, O. R., Naik, V., Holloway, J., Johnson, B. J., Middlebrook, A. M., Oltmans, S. J., Pollack, I. B., Ryerson, T. B., Warner, J. X., Wiedinmyer, C., Wilson, J., and Wyman, B.: Transport of Asian ozone pollution into surface air over the western United States in spring, J. Geophys. Res.-Atmos., 117, 1-20, doi:10.1029/2011JD016961, 2012.

Lock, A. P., Brown, A. R., Bush, M. R., Martin, G. M., Smith, R. N. B., Ock, A. P. L., Rown, A. R. B., Ush, M. R. B., and Artin, G. M. M.: A new boundary layer mixing scheme - Part I: Scheme description and single-column model tests, Mon. Weather Rev., 128, 3187-3199, doi:10.1175/15200493(2000)128<3187:ANBLMS>2.0.CO;2, 2000.

Lothon, M., Lohou, F., Pino, D., Couvreux, F., Pardyjak, E. R., Reuder, J., Vilà-Guerau de Arellano, J., Durand, P., Hartogensis, O., Legain, D., Augustin, P., Gioli, B., Lenschow, D. H., Faloona, I., Yagüe, C., Alexander, D. C., Angevine, W. M., Bargain, E., Barrié, J., Bazile, E., Bezombes, Y., Blay-Carreras, E., van de Boer, A., Boichard, J. L., Bourdon, A., Butet, A., Campistron, B., de Coster, O., Cuxart, J., Dabas, A., Darbieu, C., Deboudt, 
K., Delbarre, H., Derrien, S., Flament, P., Fourmentin, M., Garai, A., Gibert, F., Graf, A., Groebner, J., Guichard, F., Jiménez, M. A., Jonassen, M., van den Kroonenberg, A., Magliulo, V., Martin, S., Martinez, D., Mastrorillo, L., Moene, A. F., Molinos, F., Moulin, E., Pietersen, H. P., Piguet, B., Pique, E., RománCascón, C., Rufin-Soler, C., Saïd, F., Sastre-Marugán, M., Seity, Y., Steeneveld, G. J., Toscano, P., Traullé, O., Tzanos, D., Wacker, S., Wildmann, N., and Zaldei, A.: The BLLAST field experiment: Boundary-Layer Late Afternoon and Sunset Turbulence, Atmos. Chem. Phys., 14, 10931-10960, doi:10.5194/acp14-10931-2014, 2014.

Mahrt, L.: Stably stratified atmospheric boundary layers, Annu. Rev. Fluid Mech., 46, 23-45, doi:10.1146/annurev-fluid-010313141354, 2014.

Malinowski, S. P., Haman, K. E., Kopec, M. K., Kumala, W., and Gerber, H.: Small-scale turbulent mixing at stratocumulus top observed by means of high resolution airborne temperature and LWC measurements, J. Phys. Conf. Ser., 318, 072013, doi:10.1088/1742-6596/318/7/072013, 2011.

Malinowski, S. P., Gerber, H., Jen-La Plante, I., Kopec, M. K., Kumala, W., Nurowska, K., Chuang, P. Y., Khelif, D., and Haman, K. E.: Physics of Stratocumulus Top (POST): turbulent mixing across capping inversion, Atmos. Chem. Phys., 13, 12171-12186, doi:10.5194/acp-13-12171-2013, 2013.

Martin, S., Beyrich, F., and Bange, J.: Observing entrainment processes using a small unmanned aerial vehicle: a feasibility study, Bound.-Lay. Meteorol., 150, 449-467, doi:10.1007/s10546-0139880-4, 2014.

McKendry, I. and Lundgren, J.: Tropospheric layering of ozone in regions of urbanized complex and/or coastal terrain: a review, Prog. Phys. Geog., 24, 329-354, doi:10.1177/030913330002400302, 2000.

Moeng, C.-M., Sullivan, P. P., and Stevens, B.: Including radiative effects in an entrainment rate formula for buoyancy-driven PBLs, J. Atmos. Sci., 56, 1031-1049, 1999.

Morris, G. A., Ford, B., Rappenglück, B., Thompson, A. M., Mefferd, A., Ngan, F., and Lefer, B.: An evaluation of the interaction of morning residual layer and afternoon mixed layer ozone in Houston using ozonesonde data, Atmos. Environ., 44, 40244034, doi:10.1016/j.atmosenv.2009.06.057, 2010.

Münkel, C., Eresmaa, N., Räsänen, J., and Karppinen, A.: Retrieval of mixing height and dust concentration with lidar ceilometer, Bound.-Lay. Meteorol., 124, 117-128, doi:10.1007/s 10546-0069103-3, 2007.

Neuman, J. A., Trainer, M., Aikin, K. C., Angevine, W. M., Brioude, J., Brown, S. S., de Gouw, J. A., Dube, W. P., Flynn, J. H., Graus, M., Holloway, J. S., Lefer, B. L., Nedelec, P., Nowak, J. B., Parrish, D. D., Pollack, I. B., Roberts, J. M., Ryerson, T. B., Smit, H., Thouret, V., and Wagner, N. L.: Observations of ozone transport from the free troposphere to the Los Angeles basin, J. Geophys. Res.-Atmos., 117, D00V09, doi:10.1029/2011JD016919, 2012.

Ouwersloot, H. G., Vilà-Guerau de Arellano, J., van Stratum, B. J. H., Krol, M. C., and Lelieveld, J.: Quantifying the transport of subcloud layer reactants by shallow cumulus clouds over the Amazon, J. Geophys. Res.-Atmos., 118, 13041-13059, doi:10.1002/2013JD020431, 2013.

Phillips, G. J., Tang, M. J., Thieser, J., Brickwedde, B., Schuster, G., Bohn, B., Lelieveld, J., and Crowley, J. N.: Signifi- cant concentrations of nitryl chloride observed in rural continental Europe associated with the influence of sea salt chloride and anthropogenic emissions, Geophys. Res. Lett., 39, L10811, doi:10.1029/2012GL051912, 2012.

Rivier, L., Peylin, P., Ciais, P., Gloor, M., Rödenbeck, C., Geels, C., Karstens, U., Bousquet, P., Brandt, J., and Heimann, M.: European $\mathrm{CO}_{2}$ fluxes from atmospheric inversions using regional and global transport models, Climatic Change, 103, 93-115, doi:10.1007/s10584-010-9908-4, 2010.

Schneider, J. and Eixmann, R.: Three years of routine Raman lidar measurements of tropospheric aerosols: Backscattering, extinction, and residual layer height, Atmos. Chem. Phys., 2, 313-323, doi:10.5194/acp-2-313-2002, 2002.

Seibert, P., Beyrich, F., Gryning, S.-E., Joffre, S., and Rasmussen, A.: Review and intercomparison of operational methods for the determination of the mixing height, Atmos. Environ., 34, 1001-1027, doi:10.1016/S1352-2310(99)00349-0, 2000.

Sinclair, V. A., Gray, S. L., and Belcher, S. E.: Controls on boundary layer ventilation: Boundary layer processes and large-scale dynamics, J. Geophys. Res., 115, D11107, doi:10.1029/2009JD012169, 2010.

Sprenger, M. and Wernli, H.: The LAGRANTO Lagrangian analysis tool - version 2.0, Geosci. Model Dev., 8, 2569-2586, doi:10.5194/gmd-8-2569-2015, 2015.

Stevens, B.: On the growth of layers of nonprecipitating cumulus convection, J. Atmos. Sci., 64, 2916-2931, doi:10.1175/JAS3983.1, 2007.

Stevens, B., Lenschow, D. H., Vali, G., Gerber, H., Bandy, A., Blomquist, B., Brenguier, J.-L., Bretherton, C. S., Burnet, F., Campos, T., Chai, S., Faloona, I., Friesen, D., Haimov, S., Laursen, K., Lilly, D. K., Loehrer, S. M., Malinowski, S. P., Morley, B., Petters, M. D., Rogers, D. C., Russell, L., SavicJovcic, V., Snider, J. R., Straub, D., Szumowski, M. J., Takagi, H., Thornton, D. C., Tschudi, M., Twohy, C., Wetzel, M., and van Zanten, M. C.: Dynamics and chemistry of marine stratocumulus DYCOMS-II, B. Am. Meteorol. Soc., 84, 579-593, doi:10.1175/BAMS-84-5-579, 2003.

Stull, R. B.: An Introduction to Boundary Layer Meteorology, vol. 13, Springer, the Netherlands, Dordrecht, doi:10.1007/97894-009-3027-8, 1988.

Sullivan, P. P., Moeng, C.-H., Stevens, B., Lenschow, D. H., and Mayor, S. D.: Structure of the entrainment zone capping the convective atmospheric boundary layer, J. Atmos. Sci., 55, 3042-3064, doi:10.1175/15200469(1998)055<3042:SOTEZC>2.0.CO;2, 1998.

Träumner, K., Kottmeier, C., Corsmeier, U., and Wieser, A.: Convective boundary-layer entrainment: short review and progress using doppler lidar, Bound.-Lay. Meteorol., 141, 369-391, doi:10.1007/s10546-011-9657-6, 2011.

Vila-Guerau de Arellano, J.: Entrainment process of carbon dioxide in the atmospheric boundary layer, J. Geophys. Res., 109, D18110, doi:10.1029/2004JD004725, 2004.

Vila-Guerau de Arellano, J., Kim, S.-W. and Barth, M. C. and Patton, E. G.: Transport and chemical transformations influenced by shallow cumulus over land, Atmos. Chem. Phys., 12, 3219-3231, doi:10.5194/acp-5-3219-2005, 2005.

Vogelezang, D. and Holtslag, A.: Evaluation and model impacts of alternative boundary-layer height formulations, Bound.-Lay. Meteorol., 81, 245-269, doi:10.1007/BF02430331, 1996. 
Wernli, H. and Davies, H. C.: A lagrangian-based analysis of extratropical cyclones. I: The method and some applications, Q. J. Roy. Meteor. Soc., 123, 467-489, doi:10.1002/qj.49712353811, 1997.

Wetter, T.: Messungen des CO- und $\mathrm{H}_{2}$-Mischungsverhältnisses im Winter 1996/97, Thesis, Johann Wolfgang Goethe University, Frankfurt am Main, 1998.

Zhang, Y., Gao, Z., Li, D., Li, Y., Zhang, N., Zhao, X., and Chen, J.: On the computation of planetary boundary-layer height using the bulk Richardson number method, Geosci. Model Dev., 7, 2599_ 2611, doi:10.5194/gmd-7-2599-2014, 2014.
Zhu, Z., Sun, X., Zhao, F. and Meixner, F.X.: Ozone concentrations, flux and potential effect on yield during wheat growth in the Northwest-Shandong Plain of China, J. Environ. Sci., 34, 19, doi:10.1016/j.jes.2014.12.022, 2015.

Zilitinkevich, S. and Baklanov, A.: Calculation of the height of the stable boundary layer in practical applications, Bound.-Lay. Meteorol., 105, 389-409, doi:10.1023/A:1020376832738, 2002. 